\title{
A Theoretical Perspective on the Relationship between Leadership Development, Knowledge Management Capability, and Firm Performance
}

\author{
Ra'ed (Moh'd Taisir) Masa'deh ${ }^{1}$, Mahmoud Mohammad Maqableh ${ }^{1} \&$ Huda Karajeh $^{2}$ \\ ${ }^{1}$ Management Information Systems Department, Faculty of Business, the University of Jordan, Jordan \\ ${ }^{2}$ Computer Information Systems, King Abdullah II School for Information Technology, the University of Jordan, \\ Jordan \\ Correspondence: Ra'ed (Moh'd Taisir) Masa'deh, Management Information Systems Department, Faculty of \\ Business, the University of Jordan, P.O. Box 13876, Amman 11942, Jordan. Tel: 96-2-6535-5000, ext. 24286. \\ E-mail: r.masadeh@ju.edu.jo
}

Received: December 11, 2013 Accepted: January 3, 2014 Online Published: February 26, 2014

doi:10.5539/ass.v10n6p128 URL: http://dx.doi.org/10.5539/ass.v10n6p128

\begin{abstract}
Since Knowledge Management (KM) is increasingly becoming an integral business function for lots of firms, as the latter recognize that competitiveness depends upon the effective management of intellectual resources, this paper aims to propose a theoretical model identifying the extent to which performing leadership development and its enablers in terms of developing training programs, possessing social capital skills, possessing human capital skills, settings goals, and deploying unique experiences; that are believed to enable knowledge management capability put into effect in the Jordanian public shareholding firms, and its impact on firm performance.
\end{abstract}

Keywords: knowledge management capability, leadership development, firm performance

\section{Introduction}

Some studies examine the critical success factors for employing KM. As reviewed by Salimi et al. (2012), some studies found various factors which were key success factor to KM (Skyrme \& Amidon, 1997). These factors contain strong link to a business imperative, a compelling vision and architecture, knowledge leadership, a knowledge creating and sharing culture, continuous learning, a well-developed technology infrastructure, and systematic organizational knowledge processes. Davenport \& Volpel (2001) found eight common success factors They were linking KM to economic performance or industry value, a clear purpose and language, a standard and flexible knowledge structure, multiple channels for knowledge transfer, a knowledge-friendly culture, a technical and organizational infrastructure, change in motivational practices, and senior management support. APQC (1999) included strategy and leadership, culture, technology and measurement in their framework as facilitators which can support the operation of KM. Chourides et al. (2003) identified various critical factors for successful KM implementation in five organizational functional areas: strategy, human resource management (HRM), Information Technology (IT), quality and marketing. Indeed, antecedents or direct enablers of knowledge management are needed to examine the latter impact on organizational performance (Chen \& Huang, 2007; Fugate et al., 2009; Kiesling et al., 2009; Holsapple \& Wu, 2011; Matzler \& Mueller, 2011; Brion et al., 2012; Chen \& Huang, 2012; Reich et al., 2012; Salimi et al., 2012; Wang \& Wang, 2012). However, by reviewing the literature, the researcher noticed that a consensus appears among the body of research concerned with the knowledge management phenomenon: the antecedents of knowledge management are recognized as necessary prerequisites for companies to realize benefits from their investments and their long term planning; besides the question of how and the extent to which firms utilize knowledge management to complement their learning orientations remains largely unexplored specially when taking into account the role of leadership development. Therefore, because there is very limited work on the relationships between knowledge management antecedents in terms of leadership development, knowledge management itself, on the organizational performance, the researcher will take them into account in the current study. The major aim of this research is to investigate the antecedents and outcomes of knowledge management to achieve higher organizational performance. 
The rest of this paper is organized as follows. It begins with the literature review regarding knowledge management capability, leadership development, and firm performance. Then, the research hypotheses are described. Next, the methodology used for the study is provided. The discussion and conclusion are then addressed.

\section{Knowledge Management Capability}

Knowledge is what a knower knows and there is no knowledge without someone knowing it (Fahey \& Prusak, 1998). Zack (1999) emphasized that firms consider knowledge to be their most valuable and strategic resource, and confirmed that the more a firm knows about its customers, products, technologies, markets, and their linkages, the better it will perform. Therefore, since knowledge is involved in most activities in firms, it has become a primary factor in their success. In addition, firms need to manage their knowledge resources more efficiently to enhance performance and produce the biggest payoffs, and to obtain a competitive advantage (Meso \& Smith, 2000). Several researchers in the KM field emphasize the importance of knowledge. For instance, Prusak (1999) in Myers (1996) offered numerous reasons to explain such values. First of all, firms are under huge pressure to stay ahead of competitors because of increased adaptability and process speed, as a result of the globalization of the economy. Also, there is increasing awareness of the value of specialized knowledge, as embodied in organizational processes and routines, in coping with the pressure of economic globalization. In addition, people are now better able to work with and learn from each other as a result of falling cost of networked computing.

Moreover, Nonaka (1994) distinguished two types of knowledge: explicit and tacit knowledge. Since explicit knowledge tends to be considered as everything that can be documented, archived, or codified, it can be contained within artifacts like paper or technology. Therefore, it could be shared (e.g. books can be passed on, databases can be consulted). Tacit knowledge is more difficult to qualify, and is retained by people in their heads. Hence, it is the product of their minds' experiences and learning. Nevertheless, in some cases it could be shared (e.g. by the use of email, chat rooms, or instant messaging as individuals tend to use such technologies informally), however, it is mostly shared in the course of story-telling and in conversations. Nonetheless, explicit knowledge of knowledge management and tacit knowledge complete each other, and both are important elements approaches in firms. Knowledge management defined as a set of business processes developed in a firm in order to create, store, transfer, and apply knowledge (Laudon \& Laudon, 2012). Murray (1998) emphasized that KM is a strategy that utilizes a firm's intellectual assets and the talents of its members to produce new products, values, and to enhance competitiveness. Some scholars (e.g. Alavi \& Leidner, 2001; Masa'deh \& Shannak, 2012; Shannak et al., 2012; Shannak, Masa'deh, \& Alkour, 2012; Masa'deh et al., 2013) emphasize the need for large firms to integrate their IT with their KM strategies and processes in order to survive in their highly competitive business environments.

Furthermore, knowledge sharing which was defined as process through which explicit or tacit knowledge is communicated to other individuals; can be clarified by three points of views. First, knowledge sharing means effective transfer, so that the recipient of knowledge can understand it well enough to act on it. Second, what is shared is knowledge rather than recommendations based on the knowledge; the former involves the recipient acquiring the shared knowledge as well as being able to take action based on it, which simply involves utilization of knowledge without the recipient internalizing the shared knowledge. Third, knowledge sharing may take place across individuals as well as across groups, departments, or organizations (Becerra-Fernandez \& Sabherwal, 2010), thus sharing knowledge is an important process in enhancing organizational innovativeness and performance (Kannan et al., 2013). However, depending on whether explicit or tacit knowledge is being shared, exchange or socialization processes are used. Socialization facilitates the sharing of tacit knowledge in cases in which new tacit knowledge is being created as well as when new tacit knowledge is not being created. There is no intrinsic difference between the socialization process when used for knowledge discovery or knowledge sharing, although the way in which the process may be used could be different.

In addition, Gharaibeh (2013) pointed to Alomary (2004) who conducted a research on commercial banks of Jordan to study the joint use of IT and KM to achieve a high value on the work of banks, data were collected from (116) manager, experts, and consultants working in (16) commercial Jordanian banks, in which the research found a strong relationship between knowledge management and high value works at the researched banks, and a strong relationship between information technology and the high value of the work. Also the study found that there is a strong relationship between the joint use of knowledge management, information technology and high value to the work of the commercial banks. Further, the researcher recommended that to take advantage of the World Wide Web (Internet) in the provision of services and enhance the value-added, to use decision support systems and expert systems, and greater attention to motivation and satisfaction of employees and support the 
achievements of users in addition to recommending the use of knowledge management in all the banks to achieve high value for their work.

Also, organizational culture has been defined as the specific collection of values and norms that are shared by people and groups in an organization and that control the way they interact with each other and with stakeholders outside the organization (Al-Azmi et al., 2012; Alkalha et al., 2012; Obeidat et al., 2012; Shannak, Obeidat, \& Masa'deh, 2012; Masa'deh, Shannak, \& Maqableh, 2013). Further, it is a pattern of shared basic assumptions that the group learned as it solved its problems of external adaptation and internal integration that has worked well enough to be considered valid and, therefore, to be taught to new members as the correct way you perceive, think, and feel in relation to those problems (Schein, 2004). Albatyneh (2007) tested three main hypotheses: the first hypothesis examined if there is an impact of the knowledge site on performance and organizational learning, and the second hypothesis concerned if there is an impact of knowledge management, which includes the organizational structure and organizational culture, infrastructure, information technology on organizational performance and organizational learning; and third hypothesis related to the effect of the exercise of knowledge management practices (i.e. the diagnosis, the acquisition and generation, storage and distribution, and application of knowledge) on organizational performance and organizational learning. The study was applied on (15) Jordanian Commercial Banks and distributed questionnaires in which (114) were used in the analysis, and the researcher recommended that banks should encourage individuals to carry out $\mathrm{KM}$ initiatives concerning individuals, setting goals, exploiting the availability of experts in the field of knowledge, and modifying the organizational structure and the availability of infrastructure for information technology and operations concerning the diagnosis and knowledge acquisition.

Gharaibeh (2013) indicated that Almaddan (2008) aimed to measure the impact of organizational culture factors on the implementation of knowledge management, in Orange Jordan Telecommunication Group. The total number of employees were (2700), the sample analysis included (270) employees at all levels which was selected randomly, and the researcher found that: there is an effect of cultural executive on knowledge management, organizational culture effect on knowledge management, also the leadership variable was the most effected on knowledge management; the other impacted factors on knowledge management were as following (workers, incentive systems, organizational processes, organizational structure, and information systems). The researcher also recommended that top management should adopt a strategy for managing incentive systems to encourage workers to be creative and innovative; and encouraging to generate knowledge in order to improve performance and enable organizational creativity and innovation.

A research conducted by Rivera-Vazquez et al. (2009) to investigate overcoming cultural barriers for innovation and knowledge sharing. A qualitative research consists of interviews, carried out to management personnel, and questionnaires submitted to the employees using the results collected from four public and private organizations. The researcher argued that organization must identify and overcome some cultural barriers to be effective in producing and sharing knowledge at the micro level which has to do with the organizational culture as it is shaped by national culture of citizens working for the organization. Rivera-Vazquez et al. (2009) found from the interview responses, the managerial level both private and public agencies have overcome the barriers that set back the knowledge sharing, while the questionnaires found that at the employee level several cultural barriers such as organizational environment, emotional intelligence and managers' commitment are still present. Moreover, the researchers recommended that this study may be used to develop standard procedures to cope with culture differences when establishing a suitable environment for knowledge production and sharing among employees.

\section{Leadership Development}

The role of IT in the organization has evolved, researchers from 1980 till now consider the IT as an enabler to achieve the competitive advantages, considered as a strategic weapon, and as a crucial support to operational and strategic business processes that has been widely accepted (Kefi \& Kalika, 2005; Altamony et al., 2012; Masa'deh, 2012). IT infrastructure flexibility is an enabler to achieve strategic business objectives; operational excellence; new products, services, and business models; customer and supplier intimacy, improved decision making; firm performance; competitive advantages; and survival (Laudon \& Laudon, 2012; Masa'deh, 2013). The concept of IT becomes from the combination of hardware and information system. An information system (IS) could be seen as a system composed of software application, support software, hardware, document and training materials, controls, job roles and peoples that use the software application. Thus, information system may help managers and workers analyze problems, visualize complex subjects, and create new product (Laudon \& Laudon, 2012). Also, the information system (IS) department can be a powerful change agent. IS departments can affect changes in the organization by suggesting new business strategies and new information-based products 
and coordinating both development of technology and the planned changes in the organization (Gottschalk \& Taylor, 2000). The decision making and planning regarding to the technologies that is used in other functions in their operations demand the CEO think how to allocate the decision making and responsibilities. CIO is responsible for the Information Systems and for enhancing these systems in accordance with business strategy. Other responsibilities include development and implementation of IT strategy and information architecture for knowledge management; improve technical infrastructure; enhancement of access to database; applications procurement; and user training and support (Gottschalk \& Taylor, 2000).

Initially leadership known as a relational process between leader and followers, and is molded by the context (Fiedler \& Chemers, 1974); while others defined it as the use of influence to encourage participation in achieving set goals (Yukl, 2006). Further, an effective leader understands social network relationships among organization members and also between members and others beyond the organization boundaries, and is able to influence individuals' personal networks for the benefit of the organization (Balkundi \& Kilduff, 2006; Galli \& Müller-Stewens, 2012). However, there is an important distinction between leader development and leadership development. Indeed, Day (2001) suggested that leader development spotlights the employees and look for enhancing their intrapersonal skills, besides enhancing their Knowledge, Skills, and Abilities (KSA). However, leadership development known as a category of human development which evolves over time, and considered to be an outcome of complex mutual communications between the leader, employees, and the social surroundings. Also, leadership entails that an employee development is included and considered within the circumstance of others; societal systems; besides organizational strategies, missions, and objectives (Olivares et al., 2007). In addition, McCauley (2001) outlines three components of leadership development: developmental experiences that provide opportunities for learning; personal orientation to learning including one's ability, skills, and motivation; and organizational support such as rewards for developmental gains.

\section{Research Hypotheses}

This study used variables that are common in information systems and management literatures. Figure 1 displays the research's proposed model.

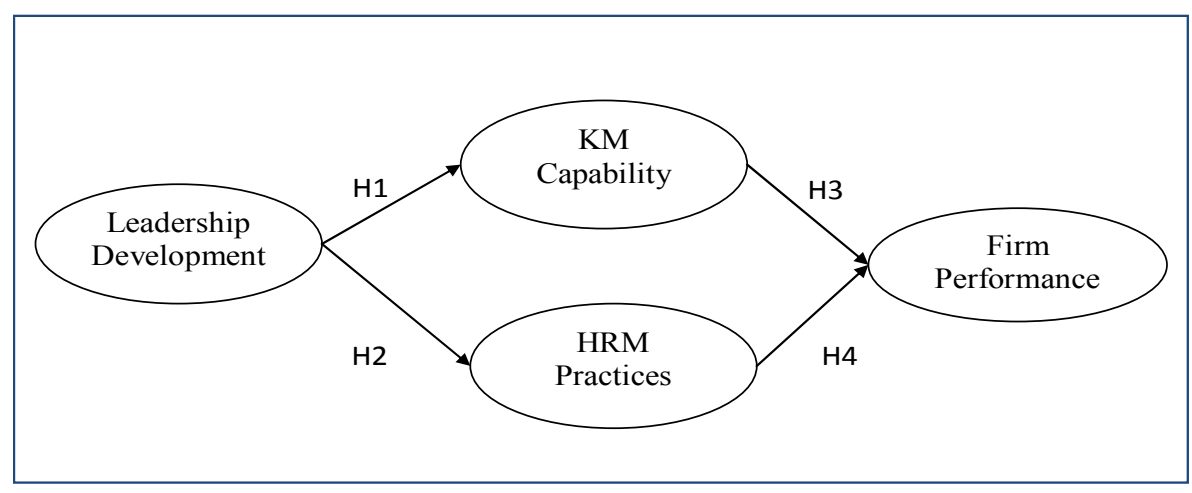

Figure 1. The research proposed model

Several leadership development antecedents play a key factor that affect leadership development. This is by exploiting classroom training sessions as well as through interventions such as mentoring, coaching, active learning, intensive feedback programs, job challenges and reassignments, and social networking (Day, 2001). Also, human and social capital capabilities are essential in impacting leadership development. While human capital enhances organizational performance as individuals apply their knowledge, skills, and abilities; social capital improves performance through networked relationships that foster cooperation and resource exchange (Day, 2001; McCallum \& O'Connell, 2009; Avolio et al., 2010). Some of the unique traits of human capital include work experience, education, knowledge, skills, and abilities; whereas some of the unique characteristics of social capital contain social awareness, self-management, forging commitments, fostering cooperation/coordination/networks; giving feedback, and establishing trust, goodwill and reciprocity (McCallum \& O'Connell, 2009). Moreover, Olivares (2008) emphasized that crucial goal setting means the hub works of human agency and that setting goals and objectives offer a rational nexus to leadership development. Further, setting goals and objectives could be well thought-out in the situation of experiences that might be valuable to leadership development. Moreover, the more leaders' have self-efficacy, the better execution of standards for achieving self-satisfaction (Wood \& Bandura, 1989). Thus, goal setting is seen as a prerequisite for achieving 
leadership development.

Furthermore, leadership development takes into consideration improving interpersonal skills, maintaining trust and obligation within and between teams and organizations, and could be considered as a base for personal development, besides it is through experiences that leaders are developed (Day, 2001; Van Velsor \& McCauley, 2004; Olivares et al., 2007). Initially, Gardner (1990) suggested that a leader's capability to lead is mainly acquired through experiences. Therefore, some scholars argued that unique experiences facilitate leadership development (Olivares, 2008). Experiences that are valuable to leadership development acquire qualities such as goal-relevant, are socially implanted, involve reflectivity, create a challenge, and improve self-efficacy. Olivares et al. (2007) found in their empirical research that experiences known as beneficial to leadership development are considered considerably higher on these qualities than those rated as non-beneficial. In other words, these elements of unique experiences are identified as beneficial to leadership development.

H1: There is a statistical positive effect of leadership development on KM capability:

The construct of leadership development is important for achieving flexible HRM practice and in turn organizational performance (McCallum \& O'Connell, 2009). For instance, performance appraisal is a powerful instrument of human resource practices; it provides information that helps making decisions about promotion, training salaries increases. Tuytens \& Devos (2012) defined the performance appraisal as "a variety of activities through which organizations seek to assess employees and develop their competence, enhance performance and distribute rewards" (p. 756). It enhances both employees and organization performance (Peretz \& Fried, 2012). In his study carried out in (2012), Lee commented that supervisors have a strong influence on their employees' behaviors due to their physical and psychological proximity to employees and due to their ability to administer rewards and punishments as well as performance ratings. He found that supervisors' leadership behavior is an important antecedent of workplace harassment and a climate of respect which provides a strategic focus that enables organizations to effectively guide employee behaviors to create a civil work environment. This is to say that leadership talk, which is defined as the communication that occurs between leader and evaluated employee, is a key. Good leadership talk helps employees to turn their negative perception to a positive one. It also assists employees to maintain a positive perception. Poor leadership talk, on the other hand, cannot turn employee positive perception to a positive one. However, it causes the possible positive perception to turn into a negative one. The outcome of the performance appraisal is the perceived benefit of it. This outcome could be positive outcomes (overcoming weaknesses and taking opportunities by focusing on strengths), or negative outcomes (absenteeism and turnover). On one hand, feedback can help leaders to reinforce the positive outcomes, and it can help to overcome those negative outcomes by developing a proper communication between the leader and his subordinates, on the other hand.

Moreover, according to Santos (2000), the human resource management practices linked with the cost reduction strategy be supposed to contain a comparatively fixed job description that does not permit ambiguities; job design and focused career definition that supports the professional specialism; performance appraisal directed by short term outcome; observing market pay stages for its use in the compensation plans; and least levels of both training and development. Also, Takeuchi (2009) argued that cost reduction can be followed throughout a flexible management policy of human resources includes an increased employ of contingent employees such as part timer, seasonal employees, and additional temporary contracted; work simplification and measurement actions; job assignment elasticity; highlighting instant technical training and development; and improved performance appraisal. He founded that a cost reduction strategy interrelates with the existence of a focused-flexible HRM. IS application used in cost strategy like TPS, Reporting Systems, and Tracking Systems enable the HR to reduce paper handling, standardizes entry and reporting, increase processing accuracy, increase report turnaround, and early warning of goal deviation. The Experts Systems decreases need for HR experts and helps spread database and training costs over entire workforce. Decision Support System (DSS) increases chance of innovation for HR cost controls. Further, there is an agreement among strategic human resource management researchers that the successful execution of the differentiation strategy necessitates employees' cultural self-improvement; encouraging employees" creativity and risk taking; improving employees' training and development schemes; and a high acceptance of uncertainty and volatility (Santos, 2000; Takeuchi, 2009). Takeuchi (2009) found that the differentiation strategy interrelated positively with performance-based HRM policy.

H2: There is a statistical positive effect of leadership development on HRM practices:

Several researchers emphasize that KM capability could be a vital mediator between IT and firm performance (Tanriverdi, 2005; Chan \& Reich, 2007; Oduwole \& Olatundun, 2010; Shannak et al., 2010; Mladkova, 2012). In 
addition, as mentioned above, performance appraisal is considered to be one of the most difficult tasks a leader should perform. Furthermore, it is proved that performance appraisal affects the future performance of employees. Accordingly, it should be carried out carefully. The role of leaders in this process is very critical to ensure meeting the goals and objectives of this process. For this, leaders should take care of the after appraisal talk to ensure the positive outcome associated with performance appraisal and avoid the negative outcome of this process. Drawing on Nahapiet \& Ghoshal (1998), Cohen \& Prusak (2001), Hitt \& Ireland (2002), Ireland \& Hitt (2005), McCallum \& O'Connell (2009) suggested five positive impacts of leadership development on organizational performance. First, it reduces transaction costs. Especially the trust developed can lead to reduced need for monitoring of trading partners. Second, social capital advances knowledge creation and sharing due to trust, shared goals and common frames of reference. Third, more comprehensible action flows from organizational stability and shared understanding. Fourth, organization membership is stabilized over reductions in turnover, severance costs, hiring and training expenses. In turn reduced personnel churning helps maintain valuable organizational knowledge. Fifth, by maximizing the values of competition and collaboration, firms enrich their chances to earn above-average financial returns. Based on above, this research hypothesized both:

H3: There is a statistical positive effect of KM capability on firm performance;

H4: There is a statistical positive effect of flexible HRM practices on firm performance.

\section{Research Methodology}

According to Smith (1983), quantitative research is associated with the traditional, positivist, experimental or empiricist paradigm, whereas qualitative research is associated with the constructivist approach, or the naturalistic, the interpretative, humanism, and post-modern perspectives. Creswell (1994, pp. 1-2) defined quantitative research as "an inquiry into a social or human problem, based on testing a theory composed of variables, measured with numbers, and analyzed with statistical procedures, in order to determine whether the predictive generalizations of the theory hold true"; whereas a qualitative study is "an inquiry process of understanding a social or human problem, based on building a complex, holistic picture, formed with words, reporting detailed views of informants, and conducted in a natural setting". In addition, since both single methodology approaches (i.e. qualitative and quantitative) have strengths and weaknesses, the combination between such approaches (i.e. employing different methods such as observations, interviews, and survey questionnaires) could be used to strengthen the validity of research (Nau, 1995; Yin, 1994, 2009). Therefore, this study primarily will use quantitative data complemented by a qualitative survey. The quantitative research will be used to investigate the hypotheses of the study, and then a qualitative research will be commenced by employing semi-structured interviews, to understand in a rich picture the association between the variables in the Jordanian public shareholding firms.

Indeed, this study mainly will use quantitative data supplemented by a qualitative survey. Firstly, the quantitative research will be used to examine the hypotheses of the study derived from the literature review. After that, qualitative research will be commenced by employing semi-structured interviews, to understand in depth the relationship between the variables in public shareholding firms in Jordan. Further, the researcher will explain in great details the philosophical basis and design of the research, and the ways in which the study will be executed. This is by explaining the research population and sample frame, the adequacy of the sample size, the development of the research variables and piloting study, the survey questionnaires translation, and data collection methods in terms of survey completing, and complementary qualitative interviews.

\section{Conclusion}

Based on literature review, the framework of this study was developed. Furthermore, the data required for this study will be collected from firms in Jordan through a questionnaire distributed to them beside semi-structured interviews. Indeed, this study contributes to the literature by filling the gap that exists in the literature where there is a lack of studies investigating the impact of knowledge management enablers on knowledge management capability, and in turn on leadership development capability and firm performance in the Jordanian firms. Moreover, the contributions of this study will be useful for both academia and practitioners. From the academic perspective, this study aspires to fill the gap of the incomplete causal chains between knowledge management capability and firm performance. Furthermore, because most knowledge management literature is theoretical and lacks empirical evidence (Chatti, 2012; Kumar \& Rose, 2012; Sáenz et al., 2012), the current study will not only provide a holistic review of the extant literature on knowledge management, but it will also be the first research of its nature to test the causal chain of knowledge management on firm performance. In addition, from the industry practitioner's perspective, this study will be of interest to IT managers and business managers in terms of their real relationships among them and their employees, and to achieve the best practices 
for managing knowledge in the firms they work for. IT and business senior management also needs to recognize the knowledge management mechanisms in which they may well transform their IT preferences into operational decision making. Consequently, the expected findings could provide useful and practical guidelines to IT managers and business managers to understand the resources and conditions required to realize the potential values of their IT investments in terms of HRM practices, and firm-based performance.

\section{References}

Alavi, M., \& Leidner, D. (2001). Review: Knowledge management and knowledge management systems: Conceptual foundations and research issues. MIS Quarterly, 25(1), 107-136. http://dx.doi.org/10.2307/3250961

Al-Azmi, N., Al-Lozi, M., Al-Zu'bi, Z., Dahiyat, S., \& Masa'deh, R. (2012). Patients' attitudes toward service quality and its impact on their satisfaction in physical therapy in KSA hospitals. European Journal of Social Sciences, 34(2), 300-314.

Albatyneh, M. (2007). The impact of knowledge management on performance and organizational learning in the Jordanian commercial banks. Unpublished PhD. Thesis, Amman Arab University, Amman, Jordan.

Alkalha, Z., Al-Zu'bi, Z., Al-Dmour, H., Alshurideh, M., \& Masa'deh, R. (2012). Investigating the effects of human resource policies on organizational performance: An empirical study on commercial banks operating in Jordan. European Journal of Economics, Finance and Administrative Sciences, 51, 44-64.

Almaddan, S. (2008). Measuring the impact of organizational culture factors in the implementation of knowledge management in the Jordan telecom group (Orange). Unpublished MSc. Thesis, Amman Arab University, Amman, Jordan.

Alomary, G. (2004). The shared use of information technology and knowledge management to achieve a high value to the work of Jordanian commercial banks. Unpublished PhD. Thesis, Amman Arab University, Amman, Jordan.

Altamony, H., Masa'deh, R., Alshurideh, M., \& Obeidat, B. (2012). Information systems for competitive advantage: Implementation of an organizational strategic management process. Proceedings of the 18th IBIMA conference on innovation and sustainable economic competitive advantage: From regional development to world economic, Istanbul, Turkey, 9th-10th May.

APQC. (1999). Knowledge management: Executive summary, consortium benchmarking study best-practice report. American Productivity \& Quality Center.

Avolio, B., Avey, J., \& Quisenberry, D. (2010). Estimating return on leadership development investment. The Leadership Quarterly, 21, 633-644. http://dx.doi.org/10.1016/j.leaqua.2010.06.006

Balkundi, P., \& Kilduff, M. (2006). The ties that lead: A social network approach to leadership. Leadership Quarterly, 17, 419-439. http://dx.doi.org/10.1016/j.leaqua.2006.01.001

Becerra-Fernandez, I., \& Sabherwal, R. (2010). Knowledge management: Systems and processes. New York: M.E. Sharpe Inc.

Brion, S., Chauvet, V., Chollet, B., \& Mothe, C. (2012). Project leaders as boundary spanners: Relational antecedents and performance outcomes. International Journal of Project Management, 30, 708-722. http://dx.doi.org/10.1016/j.ijproman.2012.01.001

Chan, Y., \& Reich, B. (2007). IT alignment: What have we learned. Journal of Information Technology, 22(4), 297-315. http://dx.doi.org/10.1057/palgrave.jit.2000109

Chatti, M. (2012). Knowledge management: A personal knowledge network perspective. Journal of Knowledge Management, 16(5), 829-844. http://dx.doi.org/10.1108/13673271211262835

Chen, C., \& Huang, J. (2007). How organizational climate and structure affect knowledge management-The social interaction perspective. International Journal of Information Management, 27, 104-118. http://dx.doi.org/10.1016/j.ijinfomgt.2006.11.001

Chen, Y., \& Huang, H. (2012). Knowledge management fit and its implications for business performance: A profile deviation analysis. Knowledge-Based Systems, 27, 262-270. http://dx.doi.org/10.1016/j.knosys.2011.11.012

Chourides, P., Longbottom, D., \& Murphy, W. (2003). Excellence in knowledge management: An empirical study to identify critical factors and performance measures. Measuring Business Excellence, 7(2), 29-45. http://dx.doi.org/10.1108/13683040310477977

Cohen, D., \& Prusak, L. (2001). In good company: How social capital makes organizations work. Boston, MA: Harvard Business School Press. 
Creswell, J. (1994). Research design: Qualitative \& quantitative approaches (1st ed.). Thousand Oaks: Sage Publications.

Davenport, T., \& Volpel, S. (2001). The rise of knowledge towards attention management. Journal of Knowledge Management, 5(3), 212-221. http://dx.doi.org/10.1108/13673270110400816

Day, D. (2001). Leadership development: A review in context. Leadership Quarterly, 11, 581-613. http://dx.doi.org/10.1016/S1048-9843(00)00061-8

Fahey, L., \& Prusak, L. (1998). The eleven deadliest sins of knowledge management. California Management Review, 40(3), 265-276. http://dx.doi.org/10.2307/41165954

Fiedler, F., \& Chemers, M. (1974). Leadership and effective management. Scott Foresman, Glenview, IL.

Fugate, B., Stank, T., \& Mentzer, J. (2009). Linking improved knowledge management to operational and organizational performance. Journal of Operations Management, 27, 247-264. http://dx.doi.org/10.1016/j.jom.2008.09.003

Galli, E., \& Müller-Stewens, G. (2012). How to build social capital with leadership development: Lessons from an explorative case study of a multibusiness firm. The Leadership Quarterly, 23, 176-201. http://dx.doi.org/10.1016/j.leaqua.2011.11.014

Gardner, J. (1990). On leadership. New York, NY: The Free Press.

Gharaibeh, A. (2013). The impact of knowledge sharing enablers on knowledge sharing capability: An empirical study on Jordanian telecommunication firms. Unpublished MSc. Thesis, Amman Arab University, Amman, Jordan.

Gottschalk, P., \& Taylor, N. (2000). Strategic management of IS/IT functions: The role of the CIO. Proceedings of the 33rd Hawaii international conference on system sciences. http://dx.doi.org/10.1109/HICSS.2000.926956

Hitt, M. A., \& Ireland, R. D. (2002). The essence of strategic leadership: Managing human and social capital. Journal of Leadership and Organizational Studies, 9, 3-14. http://dx.doi.org/10.1177/107179190200900101

Holsapple, C., \& Wu, J. (2011). An elusive antecedent of superior firm performance: The knowledge management factor. Decision Support Systems, 52, 271-283. http://dx.doi.org/10.1016/j.dss.2011.08.003

Ireland, R. D., \& Hitt, M. A. (2005). Achieving and maintaining strategic competitiveness in the 21 st century: The Role of Strategic Leadership. Academy of Management Executive, 19, 63-77. http://dx.doi.org/10.5465/AME.2005.19417908

Kanaan, R., Masa'deh, R., \& Gharaibeh, A. (2013). The impact of knowledge sharing enablers on knowledge sharing capability: An empirical study on Jordanian telecommunication firms. European Scientific Journal, 9(22), 237-258.

Kefi, H., \& Kalika, M. (2005). Survey of strategic alignment impacts on organizational performance in international European companies. Proceedings of the 38th Hawaii international conference on system sciences. http://dx.doi.org/10.1109/HICSS.2005.570

Kiesling, T., Richey, R., Meng, J., \& Dabic, M. (2009). Exploring knowledge management to organizational performance outcomes in a transitional economy. Journal of World Business, 44, 421-433. http://dx.doi.org/10.1016/j.jwb.2008.11.006

Kumar, N., \& Rose, R. (2012). The impact of knowledge sharing and Islamic work ethic on innovation capability. Cross Cultural Management, 19(2), 142-165. http://dx.doi.org/10.1108/13527601211219847

Laudon, K., \& Laudon, J. (2012). Management information systems: Managing the digital firm (12th ed.). England: Pearson.

Lee, J. (2012). The effects of leadership behavior on workplace harassment, employee outcomes, and organizational effectiveness in small businesses. PhD Thesis, The Faculty of School of Business of The George Washington University.

Masa'deh, R. (2012). The impact of Management Information Systems (MIS) on Quality Assurance (QA): A case study in Jordan. International Journal of Information, Business and Management, 4(2), 93-110.

Masa'deh, R. (2013). The impact of information technology infrastructure flexibility on firm performance: An empirical study of Jordanian public shareholding firms. Jordan Journal of Business Administration, 9(1), 204-224.

Masa'deh, R., \& Shannak, R. (2012). Intermediary effects of knowledge management strategy and learning orientation on strategic alignment and firm performance. Research Journal of International Studies, 24, 
112-128.

Masa'deh, R., Gharaibeh, A., Maqableh, M., \& Karajeh, H. (2013). An empirical study of antecedents and outcomes of knowledge sharing capability in Jordanian telecommunication firms: A structural equation modeling approach. Life Science Journal, 10(4), 2284-2296.

Masa'deh, R., Shannak, R., \& Maqableh, M. (2013). A structural equation modeling approach for determining antecedents and outcomes of students' attitude toward mobile commerce adoption. Life Science Journal, 10(4), 2321-2333.

Matzler, K., \& Mueller, J. (2011). Antecedents of knowledge sharing-examining the influence of learning and performance orientation. Journal of Economic Psychology, 32, 317-329. http://dx.doi.org/10.1016/j.joep.2010.12.006

McCallum, S., \& O’Connell, D. (2009). Social capital and leadership development: Building stronger leadership through enhanced relational skills. Leadership \& Organization Development Journal, 30(2), 152-166. http://dx.doi.org/10.1108/01437730910935756

McCauley, S. (2001). Leader training and development. In S. J. Zaccaro, \& R. J. Klimoski (Eds.), The nature of organizational leadership (pp. 347-383). CA: Jossey-Bass, San Francisco.

Meso, P., \& Smith, R. (2000). A resource-based view of organizational knowledge management systems. Journal of Knowledge Management, 4(3), 224-234. http://dx.doi.org/10.1108/13673270010350020

Mladkova, L. (2012). Sharing tacit knowledge within organizations: Evidence from the Czech Republic. Global Journal of Business Research, 6(2), 105-115.

Murray, P. (1998). New language for new leverage: The terminology of knowledge management, corporate education. NY: Biz, LLC. Retrieved from http://www.ktic.com/topic6/13_term2.htm

Myers, P. (1996). Knowledge management and organizational design. Oxford: Butterworth-Heinemann.

Nahapiet, J., \& Ghoshal, S. (1998). Social capital, intellectual capital, and the organizational advantage. Academy of Management Review, 23, 242-266.

Nau, D. (1995). Mixing methodologies: Can bimodal research be a viable post-positivist tool? The Qualitative Report, 2(3), 1-5.

Nonaka, I. (1994). A dynamic theory of organizational knowledge creation. Organization Science, 5(1), 14-37. http://dx.doi.org/10.1287/orsc.5.1.14

Obeidat, B., Shannak, R., Masa'deh, R., \& Al-Jarrah, I. (2012). Toward better understanding for Arabian culture: Implications based on Hofstede's cultural model. European Journal of Social Sciences, 28(4), 512-522.

Oduwole, A., \& Olatundun, O. (2010). Electronic technology tools for knowledge management by health. Journal of Hospital Librarianship, 10, 305-314. http://dx.doi.org/10.1080/15323269.2010.491722

Olivares, O. (2008). The formulation of leadership development praxis: Linking intentions to outcomes. Leadership \& Organization Development Journal, 29(6), 530-543. http://dx.doi.org/10.1108/01437730810894186

Olivares, O., Peterson, G., \& Hess, K. (2007). An existential-phenomenological framework for understanding leadership development experiences. Leadership \& Organizational Development Journal, 28(1), 76-91. http://dx.doi.org/10.1108/01437730710718254

Peretz, H., \& Fried, Y. (2012). National cultures, performance appraisal practices, and organizational absenteeism and turnover: A study across 21 countries. Journal of Applied Psychology, 97(2), 448-459. http://dx.doi.org/10.1037/a0026011

Prusak, L. (1999). Enemies and enabler of KM. In J. Chatzkell (Ed.), Enterprise intelligence world summit: Annual knowledge conference and exposition. Retrieved from http://www.progressivepracticies.com/

Reich, B., Gemino, A., \& Sauer, C. (2012). Knowledge management and project-based knowledge in it projects: A model and preliminary empirical results. International Journal of Project Management, 30, 663-674. http://dx.doi.org/10.1016/j.ijproman.2011.12.003

Rivera-Vazquez, J., Ortiz-Fournier, L., \& Flores, F. (2009). Overcoming cultural barriers for innovation and knowledge sharing. Journal of Knowledge Management, 13(5), 257-270. http://dx.doi.org/10.1108/13673270910988097

Sáenz, J., Aramburu, N., \& Blanco, C. (2012). Knowledge sharing and innovation in Spanish and Colombian high-tech firms. Journal of Knowledge Management, 16(6), 919-933. http://dx.doi.org/10.1108/13673271211276191 
Salimi, E., VahdatZad, V., \& Abdi, F. (2012). Key dimensions to deploy a knowledge management system in an Iranian firm: A case study. Procedia Technology, 1, 268-274. http://dx.doi.org/10.1016/j.protcy.2012.02.055

Santos, F. (2000). Integration of human resource management and competitive priorities of manufacturing strategy. International Journal of Operation \& Production Management, 20, 610-628. http://dx.doi.org/10.1108/01443570010318986

Schein, E. H. (2004). Organizational culture and leadership. San Francisco, CA: Jossey-Bass Publishers.

Shannak, R., Masa'deh, R., \& Akour, M. (2012). Knowledge management strategy building: Literature review. European Scientific Journal, 8(15), 143-168.

Shannak, R., Masa'deh, R., Al-Zu'bi, Z., Obeidat, B., Alshurideh, M., \& Altamony, H. (2012). A theoretical perspective on the relationship between knowledge management systems, customer knowledge management, and firm competitive advantage. European Journal of Social Sciences, 32(4), 520-532.

Shannak, R., Masa'deh, R., Obeidat, B., \& Almajali, D. (2010). Information technology investments: A literature review (pp. 1356-1368). Proceedings of the 14th IBIMA conference on global business transformation through innovation and knowledge management: An academic perspective, Istanbul-Turkey, 23rd-24th June.

Shannak, R., Obeidat, B., \& Masa'deh, R. (2012). Culture and the implementation process of strategic decisions in Jordan. Journal of Management Research, 4(4), 257-281. http://dx.doi.org/10.5296/jmr.v4i4.2160

Skyrme, D., \& Amindo, D. (1997). Creating the knowledge based business. London: Business Intelligence Ltd.

Smith, J. (1983). Quantitative versus qualitative research: An attempt to clarify the issue. Educational Researcher, 12, 6-13. http://dx.doi.org/10.3102/0013189X012003006

Takeuchi, N. (2009). How Japanese manufacturing firms align their human resource policies with business strategies: Testing a contingency performance prediction in a Japanese context. The International Journal of Human Resource Management, 20(1), 34-56. http://dx.doi.org/10.1080/09585190802528227

Tanriverdi, H. (2005). Information technology relatedness, knowledge management capability and performance of multibusiness firms. MIS Quarterly, 29(2), 311-334.

Tuytens, M., \& Devos, G. (2012). Importance of system and leadership in performance appraisal. Journal of Personnel Review, 41(6), 756-776. http://dx.doi.org/10.1108/00483481211263692

Van Velsor, E., \& McCauley, C. D. (2004). Introduction: Our view of leadership development. In C. D. McCauley, \& E. Van Velsor (Eds.), The center for creative leadership handbook of leadership development (2nd ed., pp. 1-22). Jossey-Bass, San Francisco, CA.

Wang, Z., \& Wang, N. (2012). Knowledge sharing, innovation and firm performance. Expert Systems with Applications, 39, 8899-8908. http://dx.doi.org/10.1016/j.eswa.2012.02.017

Wood, R., \& Bandura, A. (1989). Social cognitive theory of organizational management. Academy of Management Review, 14, 361-384.

Yin, R. (1994a). Case study research: Design and methods. Thousand Oaks: Sage Publications.

Yin, R. (2009b). Case study research: Design and methods (4th ed.). Thousand Oaks: Sage Publications.

Yukl, G. (2006). Leadership in organizations. Pearson Education, Upper Saddle River, NJ.

Zack, M. (1999). Developing a knowledge strategy. California Management Review, 41(3), 125-144. http://dx.doi.org/10.2307/41166000

\section{Copyrights}

Copyright for this article is retained by the author(s), with first publication rights granted to the journal.

This is an open-access article distributed under the terms and conditions of the Creative Commons Attribution license (http://creativecommons.org/licenses/by/3.0/). 